\section{Commentary: The great equalizer}

\author{
DuyKhanh P. Ceppa, MD
}

It has been more than 25 years since the first large case series of thoracoscopic lobectomy was published. ${ }^{1}$ Since then, the safety of this technique, along with its clinical benefit compared with thoracotomy lobectomy, has been irrefutably established. ${ }^{2-4}$ As the volume of thoracoscopic lobectomy increased, thoracotomy lobectomy volume decreased. ${ }^{5}$ Concurrently, robotic lobectomy was introduced as an alternative minimally invasive lobectomy technique and, comparatively, has been more readily adopted than thoracoscopic lobectomy.

Thoracoscopic lobectomy has known risks and complications, including $26 \%$ any and $8 \%$ pulmonary complications, $8 \%$ prolonged air leak, $7 \%$ atrial fibrillation, $1 \%$ bleeding, $2 \%$ transfusion, and $1 \% 30$-day mortality rates. ${ }^{2}$ Reported conversion rates have ranged from $3 \%$ to $20 \%$, and the reported learning curve for performing an adequate thoracoscopic lobectomy is $50 .{ }^{1,6,7}$ While minimally invasive lobectomy is considered the standard of care for early-stage lung cancer, especially for stage I disease, the complexity of these procedures must not be forgotten nor taken for granted.

In their video submission, "Potential Surgical Challenge: Hooking the Staple Stump," Matsui and Marakawa ${ }^{8}$ remind us of just that point. As the dissection is proceeding along beautifully and the audience admires the anatomy, the stump of an already-ligated branch of the pulmonary artery gets caught in the I-piece of the Endo GIA stapler load. Any thoracic surgeon cannot help but cringe witnessing this occurrence. Thankfully, the surgeons identified the error before undue tension is placed on the stump to cause avulsion; the stump is gently detached from the stapler load; and

From the Division of Cardiothoracic Surgery, Department of Surgery, Indiana University School of Medicine, Indianapolis, Ind.

Disclosures: The author reported Astra Zeneca (consultant) and Medtronic (consultant).

The Journal policy requires editors and reviewers to disclose conflicts of interest and to decline handling or reviewing manuscripts for which they may have a conflict of interest. The editors and reviewers of this article have no conflicts of interest.

Received for publication Nov 15, 2021; revisions received Nov 15, 2021; accepted for publication Dec 2, 2021; available ahead of print Jan 12, 2022.

Address for reprints: DuyKhanh P. Ceppa, MD, Division of Cardiothoracic Surgery, Department of Surgery, Indiana University School of Medicine, 545 Barnhill Dr, EH 215, Indianapolis, IN 46202 (E-mail: dpceppa@iupui.edu).

JTCVS Techniques 2022;11:80

2666-2507

Published by Elsevier Inc. on behalf of The American Association for Thoracic Surgery. This is an open access article under the CC BY-NC-ND license (http:// creativecommons.org/licenses/by-nc-nd/4.0/).

https://doi.org/10.1016/j.xjtc.2021.12.002

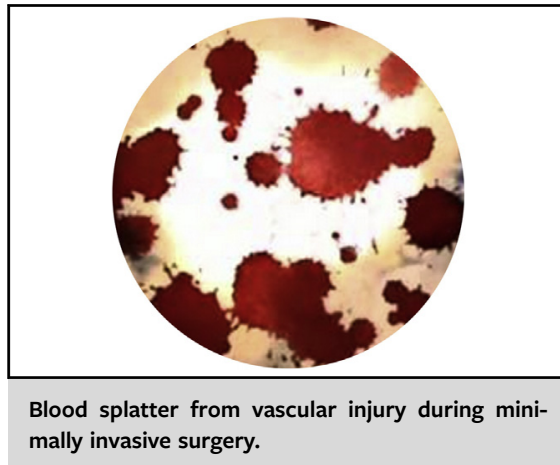

CENTRAL MESSAGE

While thoracoscopic lobectomy

has been around for more than

25 years, its complexity remains.

the procedure continues without event. As simple as this video and the solution to this technical problem may seem, it serves as a refreshing reminder that no matter how experienced one may be at thoracoscopic lobectomy, this is a challenging procedure, and adverse events happen. A surgeon's astuteness in prevention, early identification, and measured reaction to the adverse event is the distinct mark of a master surgeon.

\section{References}

1. McKenna RJ Jr. Lobectomy by video-assisted thoracic surgery with mediastinal node sampling for lung cancer. J Thorac Cardiovasc Surg. 1994;107:879-81; discussion 881-2.

2. Paul S, Altorki NK, Sheng S, Lee PC, Harpole DH, Onaitis MW, et al. Thoracoscopic lobectomy is associated with lower morbidity than open lobectomy: a propensity-matched analysis from the STS database. J Thorac Cardiovasc Surg. 2010;139:366-78.

3. Scott WJ, Allen MS, Darling G, Meyers B, Decker PA, Putnam JB, et al. Video-assisted thoracic surgery versus open lobectomy for lung cancer: a secondary analysis of data from the American College of Surgeons Oncology Group Z0030 randomized clinical trial. J Thorac Cardiovasc Surg. 2010;139:976-81; discussion 981-3.

4. Swanson SJ, Meyers BF, Gunnarsson CL, Moore M, Howington JA, Maddaus MA, et al. Video-assisted thoracoscopic lobectomy is less costly and morbid than open lobectomy: a retrospective multiinstitutional database analysis. Ann Thorac Surg. 2012;93:1027-32.

5. Subramanian MP, Liu J, Chapman WC Jr, Olsen MA, Yan Y, Liu Y, et al. Utilization trends, outcomes, and cost in minimally invasive lobectomy. Ann Thorac Surg. 2019;108:1648-55.

6. Nomori H, Horio H, Naruke T, Suemasu K. What is the advantage of a thoracoscopic lobectomy over a limited thoracotomy procedure for lung cancer surgery? Ann Thorac Surg. 2001;72:879-84.

7. Puri V, Gaissert HA, Wormuth DW, Grogan EL, Burfeind WR, Chang AC, et al. Defining proficiency for the Society of Thoracic Surgeons participants performing thoracoscopic lobectomy. Ann Thorac Surg. 2019;107:202-8.

8. Matsui H, Murakawa T. Potential surgical challenge: hooking the staple stump. J Thorac Cardiovasc Surg Tech. 2022;11:76-7. 